\title{
USE OF BACILLUS PUMILUS CBMAI 0008 AND PAENIBACILLUS SP. CBMAI 868 FOR COLOUR REMOVAL FROM PAPER MILL EFFLUENT
}

\author{
Patrícia Lopes de Oliveiraa $^{1 *}$; Marta Cristina Teixeira Duarte ${ }^{1}$; Alexandre Nunes Ponezi ${ }^{1}$; Lúcia Regina Durrant ${ }^{2}$ \\ ${ }^{1}$ Divisão de Microbiologia, Centro Pluridisciplinar de Pesquisas Químicas, Biológicas e Agrícolas, Universidade Estadual de \\ Campinas, Campinas, SP, Brasil; ${ }^{2}$ Laboratório de Sistemática e Fisiologia Microbiana, Faculdade de Engenharia de Alimentos, \\ Universidade Estadual de Campinas, Campinas, SP, Brasil.
}

Submitted: May 13, 2008; Returned to authors for corrections: July 02, 2008; Approved: March 31, 2009.

\begin{abstract}
Bacillus pumilus and Paenibacillus sp. were applied on the paper mill effluent to investigate the colour remotion. Inocula were individually applied in effluent at $\mathrm{pH}$ 7.0, 9.0 and 11.0. The real colour and COD remotion after $48 \mathrm{~h}$ at $\mathrm{pH} 9.0$ were, respectively, $41.87 \%$ and $22.08 \%$ for $B$. pumilus treatment and $42.30 \%$ and $22.89 \%$ for Paenibacillus sp. Gel permeation chromatography was used to verify the molar masses of compounds in the non-treated and treated effluent, showing a decrease in the compounds responsible for the paper mill effluent colour.
\end{abstract}

Key words: Bacillus pumilus; Paenibacillus sp.; colour removal; paper mill effluent.

\section{INTRODUCTION}

The paper industries clearly have to face more severe legal restrictions concerning environmental pollution. The new laws have been forced the paper companies to implement relevant changes in their manufacturing processes (7).

One of the specific problems that have not been solved until now is the strong dark colour of the effluents, which is primarily due to lignin and its derivatives released from the substrate and discharged in the effluents, mainly from the pulping, bleaching and chemical recovery stages (11). Dark colour of the effluent is not only aesthetically unacceptable but can increase water temperature and decrease the photosynthesis; both can lead to decreased concentration of dissolved oxygen (5). Lignin and its derivatives are difficult to degrade because of the molecule linkages, especially the biphenyl type carbon-to-carbon linkages.

Bacterial aerobic and anaerobic treatment systems can reduce the biological oxygen demand (BOD) and are able to remove the dark colour in the effluents as verified previously $(14,15)$. However, even though some physical and chemical methods quite effective in decolorization of pulp and paper mill effluents present severe setbacks such as high cost per unit volume of wastewater treated or unreliability in operation $(4,17)$.

Several researches have shown that a group of extracellular isoenzymes, known as ligninases, which are lignin peroxidase (LiP), manganese-dependent peroxidase (MnP) and laccase, produced by some microrganisms are capable of degrading lignin present in the paper mill effluent. This treatment can be a more cost effective alternative. Bacillus pumilus CBMAI 0008 and Paenibacillus sp. CBMAI 868 previously isolated, respectively, from wood decomposition material and paper mill effluent were identified by the Coleção Brasileira de Microrganismos de Ambiente e Indústria - CBMAI and are able to produce alkaline enzymes under thermophilic conditions, including xylanases and manganese-dependent peroxidase $(1,2,3,8,10)$. In this study we evaluated the ability of these bacteria for colour removal of the paper mill effluent.

\section{MATERIALS AND METHODS}

\section{Effluent source}

Effluent from first extraction of the bleaching sequence was collected from a paper industry, located in Americana - SP,

*Corresponding Author. Mailing address: 'Divisão de Microbiologia - Centro Pluridisciplinar de Pesquisas Químicas, Biológicas e Agrícolas, CPQBAUNICAMP, Caixa Postal 6171. CEP 13083-080, Campinas, SP, Brasil. E-mail: patricia_lopes13@yahoo.com.br 
Brazil. For the study, samples from acidic $(\mathrm{pH}=3.0)$ and alkaline $(\mathrm{pH}=12.0)$ treatments were collected and mixed to reach the desirable $\mathrm{pH}$ ( $\mathrm{pH} 7.0, \mathrm{pH} 9.0$ and $\mathrm{pH} 11)$. Samples were filtered to remove large suspended particles and stored at $25^{\circ} \mathrm{C}$ until use.

\section{Microorganisms.}

Bacillus pumilus CBMAI 0008 was isolated from wood decomposition material by Duarte et al. (1) and was maintained in a culture medium containing birchwood xylan (6). Paenibacillus sp. CBMAI 868 was isolated from paper mill wastewater, in a previously study (10) in a medium containing (\%): birchwood xylan (Sigma), 1; $\left(\mathrm{NH}_{4}\right)_{2} \mathrm{SO}_{4}, 0.1$; paper mill wastewater, 50; agar-agar, 2 . The medium was sterilized at $121^{\circ} \mathrm{C}$ for $15 \mathrm{~min}$, and nistatin $\left(44.0 \mathrm{mg} . \mathrm{L}^{-1}\right)$ was added as an antifungal control. Both bacteria were isolated at $45^{\circ} \mathrm{C}$ and are able to growth and produce enzymes in this condition.

\section{Inocula preparation}

The cultures were individually transferred to $125 \mathrm{~mL}$ Erlenmeyer flasks, containing $12.5 \mathrm{~mL}$ of the liquid medium (6), and incubated at $45^{\circ} \mathrm{C}$ in a rotary shaker $(250 \mathrm{rpm})$ for $20 \mathrm{~h}$. Indulin AT $(0,1 \% \mathrm{w} / \mathrm{v})$ was added as inducer in the medium from Paenibacillus sp., once this stimulate manganese-dependent peroxidase production by this bacterium as demonstrated in a previous study (10). After growth cell concentrations of the two different cultures were adjusted to $3 \% \mathrm{~T}$ (transmittance) in relation to distilled water at $600 \mathrm{~nm}$.

\section{Decolorization studies}

B. pumilus and Paenibacillus sp. were investigated individually in the crude paper mill effluent at $\mathrm{pH}$ values adjusted as described previously. Decolorization tests were conducted in $250 \mathrm{~mL}$ Erlenmeyer flasks, containing $100 \mathrm{~mL}$ of effluent. After bacteria inoculation $\left(8 \% \mathrm{v} / \mathrm{v}\right.$, equivalent to $\left.10^{8} / \mathrm{mL}\right)$, the flasks were incubated under $200 \mathrm{rpm}$ at $45^{\circ} \mathrm{C}$ during $24 \mathrm{~h}$ or $48 \mathrm{~h}$, and were centrifuged at $10.000 \mathrm{rpm}$ under refrigeration.

\section{Real colour measurement}

Real colour was measured according to Standard Methods (16). Colour was determined in a HACH - model DR2010 spectrophotometer at $455 \mathrm{~nm}$. Colour quantification was done through directly reading of untreated and treated effluent samples. Results were expressed in $\mathrm{mg} \mathrm{Pt}-\mathrm{Co} / \mathrm{L}$.

\section{Chemical oxygen demand measurement}

Chemical oxygen demand (COD) was determined in untreated and treated effluent by a closed reflux colorimetric method (method 5220 C) according to Standard Methods (16). A HACH - model DRB 200A was used for digestion of sample in COD vials. COD was spectrophotometrically determined at $600 \mathrm{~nm}$.

\section{Gel permeation chromatography}

The molecular weight distribution in untreated and treated effluent (best colour remotion and COD results) was determined by loading $2 \mathrm{~mL}$ of each sample (centrifuged effluent samples supernatant) onto a Sephadex G-75 resin (KX-16 100/16). The resin was previously equilibrated with $\mathrm{NaOH}(0.002 \mathrm{~g} / \mathrm{L})$ and $\mathrm{LiCl}(0.848 \mathrm{~g} / \mathrm{L})$ in isocratic system, flow at $2.0 \mathrm{~mL} / \mathrm{min}$, connected to a GradiFrac (Pharmacia Biotech) (12). Sample elution was monitored by $\mathrm{OD}_{280 \mathrm{~nm}}$ in a Pharmacia LKB UV-1 detector.

\section{RESULTS AND DISCUSSION}

\section{Effluent Decolorization}

As reported for fungi in previous studies, the decolorization tests of the paper mill effluent was carried out using whole cell of each bacteria. The real colour of the untreated effluent at $\mathrm{pH}$ $7.0,9.0$ and 11.0 were, respectively, 887,781 and $597 \mathrm{mg} \mathrm{Pt-Co} /$ L. The percentage of real colour reduction after $24 \mathrm{~h}$ and $48 \mathrm{~h}$ using B. pumilus and Paenibacillus sp. treatments are shown in Table 1. According to results, the treatment using Paenibacillus sp., in general, was more efficient than B. pumilus treatment, and was more pronounced at $\mathrm{pH}$ 7.0. In this condition, Paenibacillus sp. reduced the effluent colour in $41.08 \%$ after $48 \mathrm{~h}$, while B. pumilus allowed $24.01 \%$ of colour reduction. At $\mathrm{pH} 9.0$ the action of the microorganisms was similar, being observed $42.30 \%$ of colour reduction for Paenibacillus sp. and $41.87 \%$ for B. pumilus.

The results from Table 1 also show that Paenibacillus sp. was efficient in a larger $\mathrm{pH}$ range than B. pumilus $(\mathrm{pH} 7.0$ to $\mathrm{pH}$ 9.0). These results suggest that the enzymatic system from two microorganisms can be different or the bacteria produce enzymes whose optimal activity occurs in different $\mathrm{pH}$ values. However, further assays must be conducted in order to determine this question.

Table 1. Effluent real colour reduction in different $\mathrm{pH}$ values after treatment with B. pumilus and Paenibacillus sp.

\begin{tabular}{cccccc}
\hline \multirow{2}{*}{$\begin{array}{c}\text { Effluent } \\
(\mathrm{pH})\end{array}$} & $\begin{array}{c}\text { Treatment } \\
\text { Time }\end{array}$ & \multicolumn{3}{c}{ Colour reduction after treatment } \\
\cline { 3 - 6 } & (h) pumilus & \multicolumn{3}{c}{ Paenibacillus $\mathrm{sp}}$. \\
\cline { 3 - 6 } & & \multicolumn{2}{c}{ Value } & $\%$ & \multicolumn{2}{c}{ Value } & $\%$ \\
\cline { 3 - 6 } & 24 & $182.99 \pm 2.62$ & 20.63 & $204.36 \pm 3.77$ & 23.04 \\
7.0 & 48 & $212.97 \pm 2.72$ & 24.01 & $364.38 \pm 1.74$ & 41.08 \\
& 24 & $228.36 \pm 2.34$ & 29.24 & $283.66 \pm 4.72$ & 36.32 \\
9.0 & 48 & $327.00 \pm 0.78$ & 41.87 & $330.36 \pm 5.78$ & 42.30 \\
& 24 & $169.67 \pm 1.25$ & 28.42 & $241.02 \pm 4.73$ & 35.85 \\
11.0 & 48 & $178.98 \pm 1.41$ & 29.98 & $188.35 \pm 1.23$ & 31.55 \\
\hline
\end{tabular}


Recent studies using ligninolytic enzymes from filamentous fungi as Aspergillus fumigatus and A. flavus showed a removal from the paper effluent colour (12). In this case, A. fumigatus was able to decolorize $55.5 \%$ under stationary condition and 89.3\% under shaking conditions, while A. flavus removed 53.5 and $84.0 \%$, respectively, in the same conditions. The difference in the colour reduction was related to differences in aeration between stationary and shaking flasks conditions. Basidiomycetes were also applied in the paper effluent aim decoloration, as Pleurotus sajor-caju, P. platypus and $P$. citrinopileatus (11). After 6 days, $P$. sajor-caju decolorized $66.7 \%$ of the effluent. These studies show a decolorization ranges between 55\% to around $90 \%$. However, in order to obtain such efficience, is necessary 3 to 6 days of treatment, which can not be applied industrially.

The use of bacterial enzymes for effluent colour removal in the paper industry was reported previously $(4,14,15)$.

In the present work, was obtained about $40 \%$ efficience in the colour decolorization after $48 \mathrm{~h}$. Further investigations should be conducted to show if an increase in the treatment time of the effluent with these bacteria, can allow the same efficiency reached for fungi.

\section{Chemical oxygen demand measurement (COD)}

Untreated and treated effluent by $B$. pumilus and Paenibacillus sp. were evaluated to COD. The media values for COD in the untreated effluent were 2157.92, 2221.68 and $2297.59 \mathrm{mg} / \mathrm{mL}$, when the $\mathrm{pH}$ was corrected to $\mathrm{pH} 7.0,9.0$ and 11.0 , respectively. The percentage of COD reduction after $24 \mathrm{~h}$ and $48 \mathrm{~h}$ from B. pumilus and Paenibacillus sp. treatment are shown in Table 2 . The results show that although not occurred important changes after $24 \mathrm{~h}$ or $48 \mathrm{~h}$, was observed a little increase in the COD reduction when the $\mathrm{pH}$ was raised from $\mathrm{pH}$ 7.0 to $\mathrm{pH}$ 11.0. Considering the efficiency in the COD reduction, about $22 \%$ at $\mathrm{pH} 9.0$ was observed for both bacteria, around

Table 2. Effluent COD reduction in different $\mathrm{pH}$ values after treatment with B. pumilus and Paenibacillus sp.

\begin{tabular}{|c|c|c|c|c|c|}
\hline \multirow{4}{*}{$\begin{array}{c}\text { Effluent } \\
(\mathrm{pH})\end{array}$} & \multirow{4}{*}{$\begin{array}{l}\text { Treatmer } \\
\text { Time } \\
\text { (h) }\end{array}$} & \multicolumn{4}{|c|}{ Colour reduction after treatment } \\
\hline & & \multicolumn{2}{|c|}{ B. pumilus } & \multicolumn{2}{|c|}{ Paenibacillus sp. } \\
\hline & & Value & $\%$ & Value & $\%$ \\
\hline & & $\mathrm{mg} / \mathrm{mL}$ & & $\mathrm{mg} / \mathrm{mL}$ & \\
\hline \multirow[t]{2}{*}{7.0} & 24 & $441.51 \pm 2.00$ & 20.46 & $412.38 \pm 2.82$ & 19.11 \\
\hline & 48 & $457.26 \pm 8.35$ & 21.19 & $418.85 \pm 3.02$ & 19.41 \\
\hline \multirow[t]{2}{*}{9.0} & 24 & $487.66 \pm 1.99$ & 21.95 & $496.32 \pm 2.26$ & 22.34 \\
\hline & 48 & $490.55 \pm 1.15$ & 22.08 & $508.54 \pm 4.50$ & 22.89 \\
\hline \multirow[t]{2}{*}{11.0} & 24 & $531 . .43 \pm 2.94$ & 23.13 & $544.52 \pm 3.89$ & 23.70 \\
\hline & 48 & $541.77 \pm 3.38$ & 23.58 & $549.35 \pm 2.90$ & 23.91 \\
\hline
\end{tabular}

half from that reported for the fungus Ceriporiopsis subvermispora. In a previous study, this microorganism was able to remove $45 \%$ of COD of the paper mill effluent also after $48 \mathrm{~h}$ (9). Another fungus, Pleurotus sajor-caju, could remove $61.3 \%$ of COD after 10 days (11), while strains of Fomes lividus and Trametes versicolor reduced paper mill effluent COD in $66.7 \%$ and $59.7 \%$, respectively, after 10 days (13). The removal observed employing fungi is very superior to those found in this work using B. pumilus and Paenibacillus sp.

\section{Gel permeation chromatography}

The molecular weight distribution of the compounds present in the untreated and treated paper effluent was determined by gel permeation chromatography. Samples of the treated effluent that showed best results in real colour remotion were selected for evaluation. The molecular weight distribution in the untreated and treated effluent for $48 \mathrm{~h}$ at $\mathrm{pH} 9.0$ is presented in Fig. 1.

The determination of the molecular size distribution in decolorized effluent is useful for determining the modification that occurs in chromotrophic groups responsible for colour (12). Through comparison of the eluted peaks from crude effluent and treated effluent with microorganisms (Fig. 1) was possible to notice a decrease in the molecular weight in this last. The peaks areas were reduced nearly $60 \%$ and $70 \%$ with B. pumilus

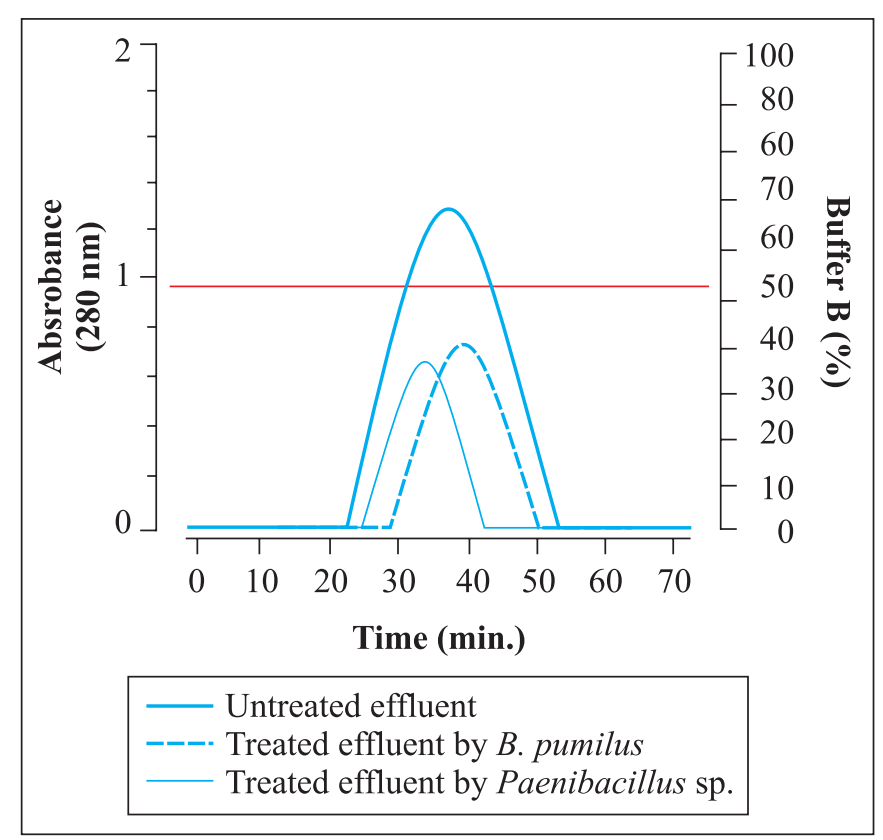

Figure 1. Sephadex G-75 ellution pattern at $280 \mathrm{~nm}$ obtained with untreated effluent and treated effluent with B. pumilus and Paenibacillus sp. at $\mathrm{pH}$ 9.0. $\mathrm{NaOH}$ and $\mathrm{LiCl}$ buffer in isocratic system, flow at $2.0 \mathrm{~mL} / \mathrm{min}$. 
and Paenibacillus sp., respectively, confirming that the compounds present in the paper effluent were depolymerized during treatment. These changes were also noticed in paper mill effluent treated with A. fumigatus (12). There was a significant decrease in high- and medium-molecular weight compounds and presence of small amount of low-molecular weight compounds in decolorized effluent, confirming the depolymerization and biochemical degradation of highmolecular weight coloured compounds by A. fumigatus. Ceriporiopsis subvermispora was also able to degrade compounds present in the paper mill effluent (9). FPLC/GPC chromatogram indicated that the macromolecules present in effluent had molecular weights of $16000 \mathrm{Da}$. After treatment with $C$. subvermispora macromolecules were degraded in low molecular weight compounds $(<1 \mathrm{kDa})$.

\section{ACKNOWLEDGMENTS}

The first author is thankful to CNPq for the scholarship.

\section{RESUMO}

\section{Emprego de Bacillus pumilus CBMAI 0008 e Paenibacillus sp. CBMAI 868 para remoção da cor do efluente da indústria papeleira}

Bacillus pumilus e Paenibacillus sp. foram aplicados separadamente no efluente da indústria papeleira a pH 7,0, 9,0 e 11,0 , para verificação da remoção da cor e da DQO. As remoções da cor real e DQO após $48 \mathrm{~h}$ a pH 9,0 foram, respectivamente, de $41,87 \%$ e $22,08 \%$ após o tratamento com B. pumilus e $42,30 \%$ e $22,89 \%$ após tratamento com Paenibacillus sp. As massas molares dos compostos presentes no efluente não tratado e tratado foram determinadas por cromatografia de permeação em gel. O emprego dos microrganismos reduziu os compostos responsáveis pela cor do efluente da indústria papeleira.

Palavras-chave: Bacillus pumilus; Paenibacillus sp.; remoção da cor; efluente da indústria papeleira.

\section{REFERENCES}

1. Duarte, M.C.T.; Portugal, E.P.; Ponezi, A.N.; Bim, M.A.; Tagliari, C.V.; Franco, T.T. (1999). Production and purification of alkaline xylanases. Biores. Technol. 68, 49-53.

2. Duarte, M.C.T.; Pellegrino, A.C.A.; Ponezi, A.N.; Portugal, E.P.; Franco, T.T. (2000). Characterization of alkaline xylanases from Bacillus pumilus. Braz. J. Microbiol. 31, 90-94.

3. Duarte, M.C.T.; Silva, E.C.; Gomes, I.M.B.; Ponezi, A.N.; Vicente, J.R.; Davanzo, E. (2003). Xylan-hydrolyzing enzyme system from Bacillus pumilus CBMAI 0008 and its effects on Eucalyptus grandis kraft pulp for pulp bleaching improvement. Bioresour. Technol. 88, 9-15.

4. Joyce, T.W.; Chang, H-M.; Campbell, A.G.; Gerrard, E.D.; Kirk, T.K. (1984). A continuous biological process to decolorize bleach plant effluents. Biotechnol. Adv. 2, 301-308.

5. Kringstad, K.P.; Lindstrom, K. (1984). Spent liquors from pulp bleaching. Environ. Sci. Technol. 18, 236-248.

6. Mandels, N.; Stenberg, D. (1976). Recent advances in cellulase technology. J. Fermentation Technol. 54, 267-286.

7. Manzanares, P.; Fajardo, S.; Martín, C. (1995). Production of ligninolytic activities when treating paper pulp effluents by Trametes versicolor. J. Biotechnol. 43, 125-132.

8. Moriya, R.Y.; Gonçalves, A.R.; Duarte, M.C.T. (2005). Sugarcane bagasse pulps - Biobleaching with commercial catarzyme HS and with Bacillus pumilus xylanase. Appl. Biochem. Biotechnol. 121, 171-181.

9. Nagarathnamma, R.; Bajpai, P.; Bajpai, P.K. (1999). Studies on decolourization, degradation and detoxification of chlorinated lignin compounds in kraft bleaching effluents by Ceriporiopsis subvermispora. Proc. Biochem. 34, 939-948.

10. Oliveira, P.L. (2008). Purificação e caracterização bioquímica de manganês peroxidase de Bacillus pumilus e Paenibacillus sp. e sua atuação na remoção da cor do efluente da indústria papeleira. São Paulo, Brasil, 69 p. (M.Sc. Dissertation, Faculdade de Engenharia de Alimentos. Unicamp).

11. Ragunathan, R.; Swaminathan, K. (2004). Biological treatment of a pulp and paper industry effluent by Pleorotus spp. World J. Microbiol. Biotechnol. 20 (4), 389-393.

12. Sahoo, D.; Gupta, R. (2005). Evaluation of ligninolytic microorganisms for efficient decolorization of a small pulp and paper mill effluent. Process Biochem. 40, 1573-1578.

13. Selvam, K.; Swaminathan, K.; Hoon Song, M.; Snag Chae, K. (2002) Biological treatment of pulp and paper industry effluent by Fomes lividus e Trametes versicolor. World J. Microbiol. Biotechnol. 18, 523-526.

14. Singh, P. (2007). Sequential anaerobic and aerobic treatment of pulp and paper mill effluent in pilot scale bioreactor. J. Env. Biol. 28, 77-82.

15. Singh, P.; Thakur, I.S. (2006). Colour removal of anaerobically treated pulp and paper mill effluent by microorganisms in two steps bioreactor. Biores. Technol. 97, 218-223.

16. Standard Methods. (2005). For examination of water e wastewater. Centennial Edition, $21^{\text {st }}$ Ed.

17. Venkataraman, T.S. (1990). Pollution abatement for small paper mills - problems and prospects. Chem. Wkly. 9, 89-94. 